\title{
Determining management units in southeastern Brazil: the case of Astyanax bimaculatus (Linnaeus, 1758) (Teleostei: Ostariophysi: Characidae)
}

\author{
Samuel Rezende Paiva ${ }^{1, *}$, Jorge Abdala Dergam $^{2}$ \& Flávia Machado ${ }^{2}$ \\ ${ }^{1}$ Embrapa Genetic Resources and Biotechnology, Final W-5 Norte, 70770-900 Brasília, DF, Brazil \\ ${ }^{2}$ Departmento de Biologia Animal, Universidade Federal de Viçosa, 36570-000 MG, Brazil \\ (*Author for correspondence: Tel.: +55-61-448-4612; Fax: +55-61-448-3624; E-mail: samuel@cenargen.embrapa.br)
}

Received 25 May 2005; in revised form 3 November 2005; accepted 3 December 2005

Key words: conservation genetics, character congruence, characiformes, genetic variability, morphometrics, RAPD

\begin{abstract}
Characterization, management and protection of biodiversity are the most prominent challenges in conservation biology. Analyses on molecular similarity (Random Amplified Polymorphic DNA-Polymerase Chain Reaction, RAPD-PCR) and morphologic patterns (morphometric and meristic characters) were performed to evaluate the existence of population structuring in the Doce river basin, in a widespread small-sized characin, Astyanax bimaculatus. Three hundred (300) individuals were collected from six locations isolated by waterfalls or dams, in the Doce river basin, Minas Gerais State, Brazil. Genetic differentiation among tributaries was significant $(p<0.00001)$ and accounted for $21 \%$ of total variance $(p<0.00001)$. Only the Grande waterfall of the Casca river was an effective factor for differentiation of populations $(p<0.00001)$, and meristic characters were also consistent with molecular data. We concluded that genetic and morphologic variation of this species was not necessarily associated with waterfalls and that molecular and meristic data are effective predictors of population divergence in this basin. The consequences of these findings for the protection and management of aquatic biodiversity were discussed.
\end{abstract}

\section{Introduction}

The Neotropical region is the richest in numbers of freshwater fishes, and may represent $25 \%$ of all species worldwide (Schaefer, 1998). This richness is dwindling due to many factors, such as habitat destruction, introduction of exotic species and pollution. Most of these changes occur in a Sentinel fashion (Meffe \& Carroll, 1997), where unknown species are extirpated before they are formally described. Typically, sampling efforts are performed shortly before implementation of irrigation projects, hydroelectric dam building or other environmentally damaging activities. As an attempt to reduce these impacts, the State of Minas Gerais, Brazil has reinforced environmental laws allowing fish transposition to the upper sections of the river (Martins \& Tamada, 2000).
However, at least some fish scales are ineffective and species-selective (e.g., Bazzoli et al., 1991), mainly because they are designed for game (such as large- or medium-sized characids) or commercially valuable species (e.g., Prochilodus spp.).

Current impact evaluation does not consider estimates of gene flow among populations occurring in different river locations (down and upriver). It is known, however, that dams may promote a halt in the gene flow process between populations of aquatic organisms, with subsequent alterations in gene frequencies of fish species (Avise \& Felley, 1979; Revaldaves et al., 1997; Neeras \& Spruell, 2001). In this study, we explored and compared the information obtained by two methods that characterize biological distinctness among populations isolated by recently built dams or by natural obstacles such as waterfalls. A small 
characin, A. bimaculatus, was studied as it is a widespread and abundant Neotropical species complex. Populations of small characins diagnosed by a round humeral spot and a caudal spot extending to the end of caudal rays were traditionally considered as subspecies of Astyanax bimaculatus (Eigenmann, 1921: 254-259). Current taxonomy acknowledges specific status for six former subspecies and four recently described species (Lima et al., 2003) that share the two spots pattern. Because A. bimaculatus of the Doce river has not been included in recent revisions, we considered it as a member of the A. bimaculatus species complex. A. bimaculatus is considered a generalist (Costa \& Braga, 1993; Esteves \& Galetti, 1995) well adapted to both running and stagnant waters (Agostinho et al., 1997). It is migratory (Uieda, 1984; Garutti, 1988), although its partial spawning reproductive regime and adhesive eggs (Bazzoli et al., 1991) are shared with other nonmigratory Neotropical freshwater fishes (Lamas, 1993). In the Neotropical region, A. bimaculatus may be considered as representative of a large number of small sized and widespread taxa that are usually neglected during ecological impact assessment studies. The genetic structure of this widespread characin may provide information on natural patterns of geographic isolation and will be a baseline for managing programs. Genetic divergence was assessed using Random Amplified Polymorphic DNA-Polymerase Chain Reaction (RAPD-PCR) markers (Welsh \& McClelland, 1990; Williams et al., 1990) and phenotypic variation included meristic and morphometric characters. Phenotypic variation is the most inexpensive approach but it must be applied on populational levels for meaningful informative value (e.g., Salducci et al., 2004). RAPD-PCR markers are cost-effective, and there is no need for previous knowledge of the species genome. These markers have been successfully applied to understand population genetics, systematics and ecology of many organisms (Hadrys et al., 1992; Fritsch \& Rieseberg, 1996; Hsiao \& Liao, 1998; Bartish et al., 1999; Lacerda et al., 2001). Despite being dominant markers, RAPD-PCR are considered very effective as long as they are: (1) performed on relatively large samples; (2) contamination problems are overcome; (3) repeatability tests are included in the pilot test; and (4) care is exercised to minimize statistical bias in estimating allelic frequencies. In comparative population studies, the effectiveness of these markers has been considered as satisfactory as isoenzymes, microsatellites, minisatellites and mitochondrial DNA (Naish et al., 1995; Aagaard et al., 1998; Nesbo et al., 1998; Sun et al., 1998).

The objective of this study was to conduct a survey on the genetic variability and population structuring presumably caused by natural barriers of $A$. bimaculatus in the rio Doce basin, and its reflection on the morphology of the species. The detected pattern represents baseline data for management, implementation or revision of current hydrologic practices that affect migration levels among populations of this species, considering the potential deleterious effects of reduced genetic diversity and the population viability.

\section{Materials and methods}

A total of 300 Astyanax bimaculatus individuals from six populations were seined or collected with

Table 1. Locales and sample sizes for molecular (N1) and morphologic (N2) analyses of A. bimaculatus in the Doce Basin

\begin{tabular}{llll}
\hline Samples (rivers) & Locale & $N 1$ & $N 2$ \\
\hline Casca (A) & Downstream from Escura Waterfall & 50 & 30 \\
Casca (B) & Between Escura and Grande Waterfalls & 50 & 30 \\
Santana (C)* & Upstream from Grande Waterfall & 50 & 30 \\
Matipó (D) & Upstream from Emboque Dam & 50 & 30 \\
Matipó (E) & Downstream from Emboque Dam & 50 & 30 \\
Sto.Antônio (F) & Near city of Ferros/MG, Brazil & 50 & 30 \\
Total & & 300 & 180 \\
\hline
\end{tabular}

\footnotetext{
*Small tributary of Casca River.
} 
gillnets in regions comprising most of the upper reaches of the Doce river basin, Minas Gerais State, Brazil (Table 1 and Fig. 1). These locales are characterized by abundant waterfalls and are therefore potential sites for future dam building projects. All individuals initially sampled were used in molecular analysis and 180 voucher specimens were used for morphologic analyses. All specimens were deposited in the Zoology Museum of the Universidade Federal de Viçosa. Epaxial muscle or gill filaments were sampled in live individuals larger than $50 \mathrm{~mm}$, while smaller specimens were fixed whole in $95 \%$ ethanol. DNA extraction was carried out with CTAB (Boyce et al., 1989). DNA pellets were resuspended in sterile TE $(0.01 \mathrm{M}$ Tris- $\mathrm{HCl}, \mathrm{pH} 7.5,0.001 \mathrm{M}$ EDTA) and stored at -20 or $-80{ }^{\circ} \mathrm{C}$ until use.
Random amplified polymorphic DNApolymerase chain reactions were processed in $20 \mu \mathrm{l}$ volume: $13.8 \mu \mathrm{l} \mathrm{H}_{2} \mathrm{O} ; 2 \mu \mathrm{l} 10 \times$ buffer $(500 \mathrm{mM}$ $\mathrm{KCl}, 100 \mathrm{mM}$ Tris- $\mathrm{HCl} \mathrm{pH}$ 8.3); $0.8 \mu \mathrm{l} 40 \mathrm{mM}$ $\mathrm{MgCl}_{2} ; 0 \cdot 2 \mu \mathrm{l}$ dNTPs $20 \mathrm{mM} ; 2 \mu \mathrm{l} 3.3 \mu \mathrm{M}$ primer (Operon Technologies) 1 unit Taq polymerase and $1 \mu \mathrm{l}$ of $25-100 \mathrm{ng}$ DNA. Reactions were carried out in a PTC100 thermocycler (MJ Research) with 40 cycles $95{ }^{\circ} \mathrm{C} 15 \mathrm{~s} ; 35^{\circ} \mathrm{C} 30 \mathrm{~s}$ and $72{ }^{\circ} \mathrm{C} 1 \mathrm{~min}$ with a final extension at $72{ }^{\circ} \mathrm{C} 7 \mathrm{~min}$. Fragments were visualized on $6 \%$ polyacrylamide gels using silver staining (Hiss et al., 1994) (Fig. 2), and all reactions included a negative control where template DNA was substituted by water.

Pilot tests were conducted with 66 primers, allowing for selection of polymorphic and sharp bands (loci). Loci were identified across gels by

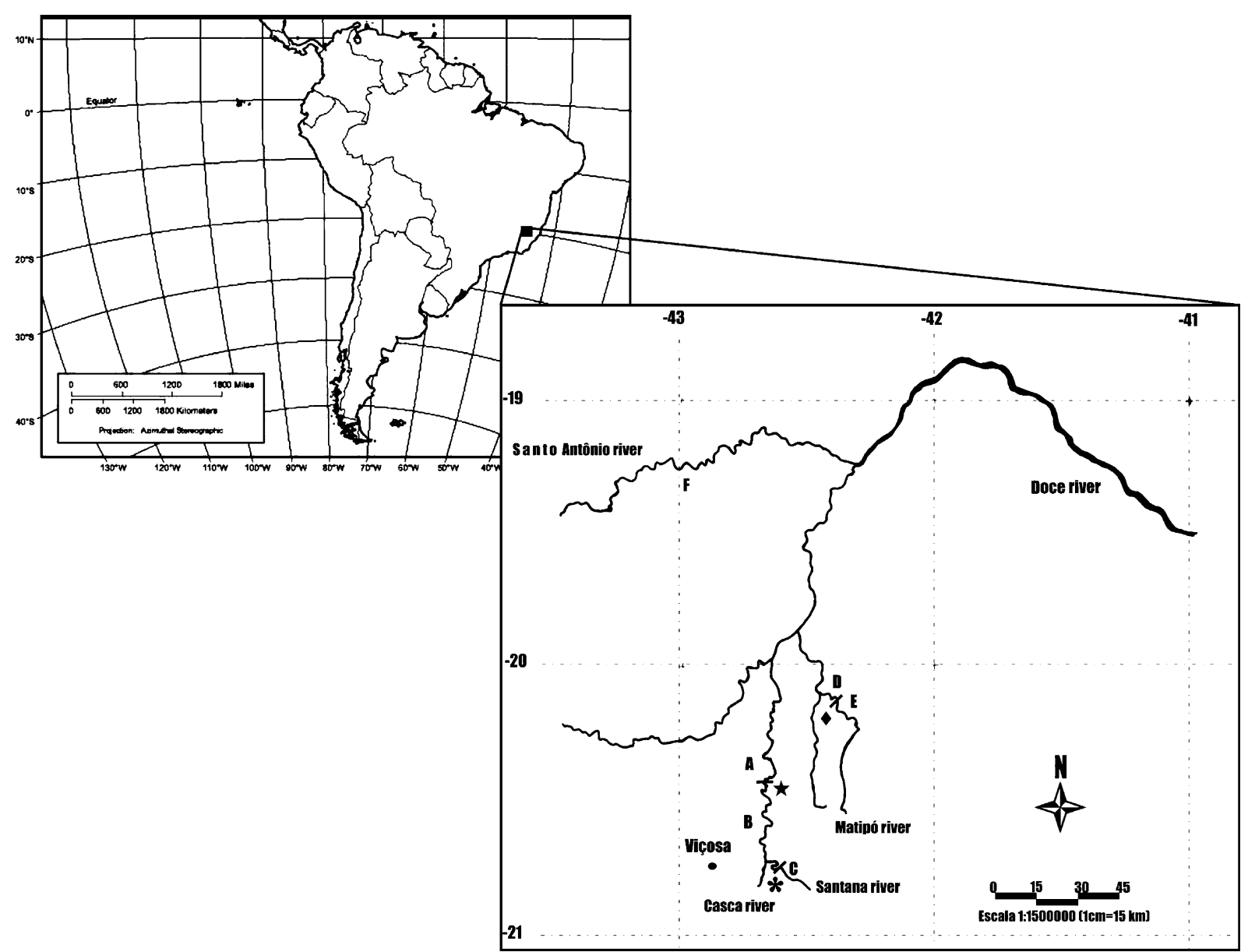

Figure 1. South America, indicating the Doce river basin in Brazil and the study area. Collecting sites and waterfalls: downstream Escura waterfall-A; river section between Escura and Grande waterfalls-B; upstream Grande waterfall-C; upstream Emboque dam-D; downstream Emboque dam-E; Ferros-F; $\bullet$ Emboque dam; $*$, Grande waterfall; $\star$, Escura waterfall. 


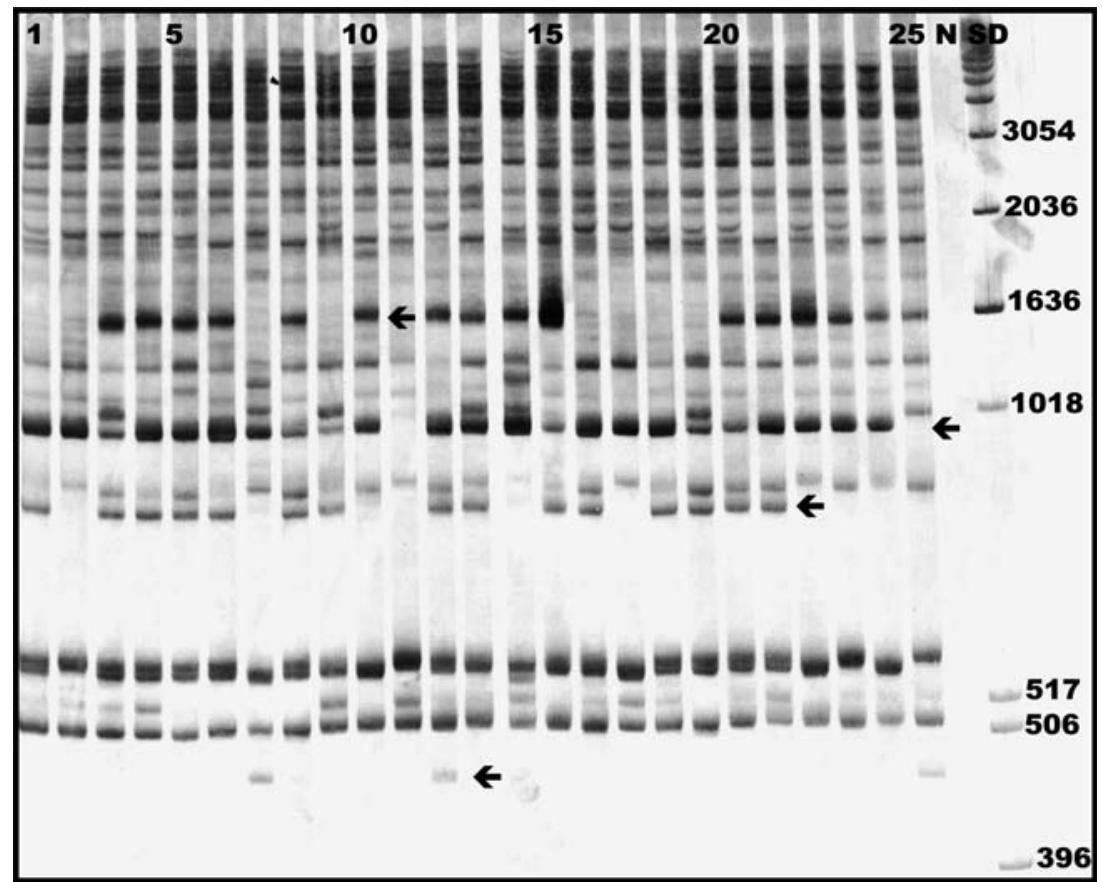

Figure 2. Example of RAPD amplifications (6\% polyacrylamide gels using silver staining) with primer OPD18 in sample of Santo Antonio river (F). Each lane (1-25) represents an individual. N, negative control; SD, 1 kb DNA Ladder (Gibco). Arrows represent polymorphic bands.

their appearance and position on the gel, according to a regression function (Schaffer \& Sederoff, 1981) relative to $1 \mathrm{~kb}$ ladder (BRL, Gibco). Repeatability tests were carried out on all selected loci in 20 randomly chosen individuals. Fragments with $90 \%$ repeatability rates were selected for analyses (Bartish et al., 1999; Vucetich et al., 2001). Approximately $70 \%$ of the primers used in the pilot study amplified successfully $A$. bimaculatus DNA and six primers (OPA01, OPA03, OPA09, OPD15, OPD18, and OPD20) were selected. Twenty-eight fragments were chosen within a size range between 460 and 1744 base pairs (estimated from gel positions).

Presence and absence were recorded on a binary matrix, and before analyses were conducted, fragments with a frequency higher than $[1-(3 / N)]$ were discarded (where $N$ is the sample in each population) for a less biased allelic estimate (Lynch \& Milligan, 1994). Statistic analyses were carried out with TFPGA - Tools For Population Genetic Analysis (Miller, 1997), Arlequin (Schneider et al., 2000) and IBD - Isolation by Distance (Bohonak, 2002). Allelic frequency was estimated from null allele (absence of fragment) frequency as $q=x^{-1 / 2}\left(1-[x(1-x) / N] / 8 x^{2}\right.$ ) (Lynch \& Milligan, 1994), where $x$ is the population proportion lacking the fragment and $N$ is sample size. Within-population variation was estimated assuming expected Hardy-Weinberg frequencies and the proportion of polymorphic loci. Bands were screened as 'diagnostic' when they were unique for some populations, and as 'characteristic' when they occurred in more than $5 \%$ of individuals of each population.

Genetic structure was estimated with Fisher's Exact Test (Raymond \& Rousset, 1995) and $F_{\mathrm{ST}}$, under null hypothesis of panmixia. A sequential Bonferroni correction (Holm, 1979) was applied to the exact $p$-values to correct critical significance levels. Effective number of migrants were estimated as $N_{\mathrm{m}}=0.25\left(1 / F_{\mathrm{ST}}-1\right)$ (Wright, 1951). Hierarchical analysis was conducted with Analysis of Molecular Variance - AMOVA (Excoffier et al., 1992) where variation was partitioned among major tributaries of the Doce river (1-Casca/Santana, 2-Matipo and 3-Santo Antônio), among samples within major tributaries (Casca/Santana 
tributary - samples A, B and C; Matipo tributary - samples D and E; Santo Antônio tributarysample F) and within populations (samples). Nei's distance (1972) was used to determine amongpopulation variability, and it was represented with an UPGMA phenogram. The collection localities were used as experimental units in this analysis. Bootstrap values (Efron, 1985) were obtained from 1000 repetitions. To determine the effects of migratory behavior of the species, a Mantel test between genetic and geographic distances was carried out (Sokal \& Rohlf, 1995).

Fifteen morphometric and two meristic characters were selected, according to Lagler et al. (1977) and Garutti \& Britski (1997). These included Standard length (SL); head length (HL); body height $(\mathrm{BH})$; caudal peduncule height $(\mathrm{CPH})$; interorbital width (IW); ocular diameter (OD); preanal distance (PD); pre-dorsal distance (PDD); dorsal-pectoral distance (DPD); pectoral-pelvic distance (PPD); pelvic-anal distance (PAD); dorsal-anal distance (DAD); anal-adipose distance (AAD); dorsal-adipose distance (DADP); head height (HH); lateral line scales (LL), and number of rays in anal (RAN). Other meristic characters were used, but only those ones were shown because were the most variable within this species complex (Garutti, 1993; Garutti \& Britski, 1997). Measures were carried out with a $0.1 \mathrm{~mm}$ digital precision caliper, transformed to base 10 logarithm to maintain allometry and to standardize variances (Jolicoeur, 1963). Statistic analyses were performed with SAS (1997) and Matlab (v.6). Data were subject to size-free canonical discriminant analysis CDA (Bookstein et al., 1985; Strauss, 1985; Reis et al., 1990; Peres-Neto, 1995). This analysis consists of removing the effect of within-group size variation by the regression of each character separately on the first pooled within-group principal component and then applying canonical discriminant analysis to the residues obtained from the regressions.

The first step in the analysis consists of centering the values for each character by the sample mean. Then the effect of size on each character was removed by regressing the values of each morphometric character on the first principal component (PC-1), thus obtaining the residuals that express variation after the removal of the withingroup size effect. Canonical discriminate analysis was then performed with the residuals obtained by the regression of each character on PC-1. The computations were continued by multiplying the intergroup covariance matrix by the inverse of the within-group covariance matrix and extracting the eigenvalues and eigenvectors from the resulting matrix. As the eigenvectors express the axes of greatest variation, they were linearly combined with the values of the morphometric characters to compose the canonical variables that produce the individual's scores. The individual's scores for each sample were plotted in the space of the canonical variables that determine the patterns of discrimination among populations. The contribution of characters to population differences was obtained using correlation vectors from the first two canonic eigenvalues for each character (Strauss, 1985).

Among-population variability of morphometric characters was estimated with D2 Mahalanobis distances, and they were depicted in a UPGMA phenogram. Phenograms obtained with molecular and morphometric data were compared using a Mantel test. Among-population variation of meristic characters histograms were plotted and significance of differences was assessed with ANOVA and contrasted with Tukey test $(\alpha=5 \%)$.

\section{Results}

\section{Molecular data}

Genic Diversity $(H)$ and proportion of polymorphic loci $(P)$ values were lowest in samples from Santo Antônio and Santana rivers, respectively (Table 2). Qualitative analysis of fragments indicated a $25 \%$ loss of alleles in Casca samples, which also displayed only one diagnostic allele. On the other extreme, Matipó samples showed the highest values of $H$ and $P$ and 11 diagnostic loci (Table 2). Most samples showed significant levels of genetic structure even after applying sequential Bonferroni correction (Table 3 ). Besides samples $B$ and C, isolated by the Cachoeira Grande $\left(\chi^{2}=92.4307\right.$, $p=0.00001)$, samples isolated by the Escura waterfall on the Casca tributary and Emboque dam on the Matipó tributary were not significantly divergent $\left(\chi^{2}=36.8373, p=0.99\right.$, and $\chi^{2}=51.4704$, $p=0.64$, respectively), as also expressed by $F_{\mathrm{ST}}$ 
Table 2. Within-population variation in populations of A. bimaculatus in the Doce basin

\begin{tabular}{llc}
\hline Samples & $H$ & $P$ \\
\hline Casca (A) & 0.2613 & 67.8571 \\
Casca (B) & 0.2537 & 67.8571 \\
Santana (C) & 0.2832 & 67.8571 \\
Matipó (D) & 0.3245 & 100 \\
Matipó (E) & 0.3579 & 96.4286 \\
Sto.Antônio (F) & 0.2441 & 85.7143 \\
\hline
\end{tabular}

$\mathrm{H}$, heterozigosity; $\mathrm{P}$, percentage of polymorphic loci $(99 \%$ criterium).

values (Table 3). Most of the genetic variation occurred within samples $(76.35 \%, p<0.00001)$; $21.04 \%(p=0.00001)$ of the genetic variance occurred among major tributaries and $2.61 \%$ $(p<0.00001)$ of the variance occurred among samples within major tributaries.

UPGMA phenograms based on Nei's (1972) distance were consistent with previous analyses, such as a high divergence of sample $\mathrm{C}$ from the Casca tributary (Fig. 3). A positive correlation was observed $(r=0.5862, p<0.00001)$ using Mantle's test between genetic and geographic distances.

\section{Morphologic data}

Principal component 1 (CP-1) explained 92.97\% of overall variation of the covariance matrix among the six samples. This component may be interpreted as a general size variable since all characters showed positive and statistically significant correlation coefficients $(r)$ (Table 4). This first eigenvector may be applied to size free Canonical Discriminant Analysis as a generalized size estimate. A regression analysis between scores of each character and CP-1 was carried out and a Size free Canonical Discriminant Analysis was applied to all samples using residuals of each character. In the resulting analysis, the two first canonic variables were responsible for $79 \%$ of observed variation $(p<0.00001)$. Canonical variables showed major overlap among populations (Fig. 4) except for some individuals from populations from the Casca (A), Santana (C), and Santo Antônio tributaries (F) (data not shown).

Correlation vectors between the values of each character and the first two canonical axes (data not shown), and CP and CV values (Table 4) indicate the characters that most contributed to levels of variation among populations. The Santo Antônio sample differed from all others in eye diameter (OD) and head length (HL); Matipó specimens were characterized by higher body height $(\mathrm{BH})$, whereas high values of pre-dorsal distance (PDD), anal adipose distance (AAD) and interorbital width (IW) characterized the Casca samples.

In contrast to the evident geographic (divergence) structure of molecular markers (Fig. 3), UPGMA dendrogram of morphometric data failed to separate samples (data not shown), and this pattern was also evident in the lack of correlation between geographic and morphologic variation (Mantel's test $r=0.0937, p=0.28$ ).

Meristic data corroborated the patterns observed with RAPD-PCR markers (Fig. 5). The $F$ statistics calculated in ANOVA was significant for both characters $(p<0.05)$. Tukey Test was applied to verify sample means that were significantly different (Fig. 5). For example, samples C and B from Santana and Casca tributaries, isolated by the Grande waterfall, differed in molecular $p<0.01$

Table 3. Estimated migrant numbers between populations of A. bimaculatus in the Doce basin

\begin{tabular}{lllllr}
\hline Samples & A & B & C & D & E \\
\hline Casca (A) & - & 23.765 & 2.305 & 0.521 & 0.523 \\
Casca (B) & 0.01041 & - & 3.477 & 0.647 & 0.630 \\
Santana (C) & $0.09783^{*}$ & $0.06707^{*}$ & - & 0.955 & 0.960 \\
Matipó (D) & $0.32419^{*}$ & $0.27876^{*}$ & $0.20749^{*}$ & - & 76.437 \\
Matipó (E) & $0.32331^{*}$ & $0.28404^{*}$ & $0.20659^{*}$ & 0.00326 & - \\
Sto.Antônio (F) & $0.25492^{*}$ & $0.19617^{*}$ & $0.14465^{*}$ & $0.11956^{*}$ & $0.13893^{*}$ \\
\hline
\end{tabular}

$* p<0.00001$.

$N_{\mathrm{m}}$ (upper matrix) and $\mathrm{F}_{\mathrm{ST}}$ values (lower matrix). 


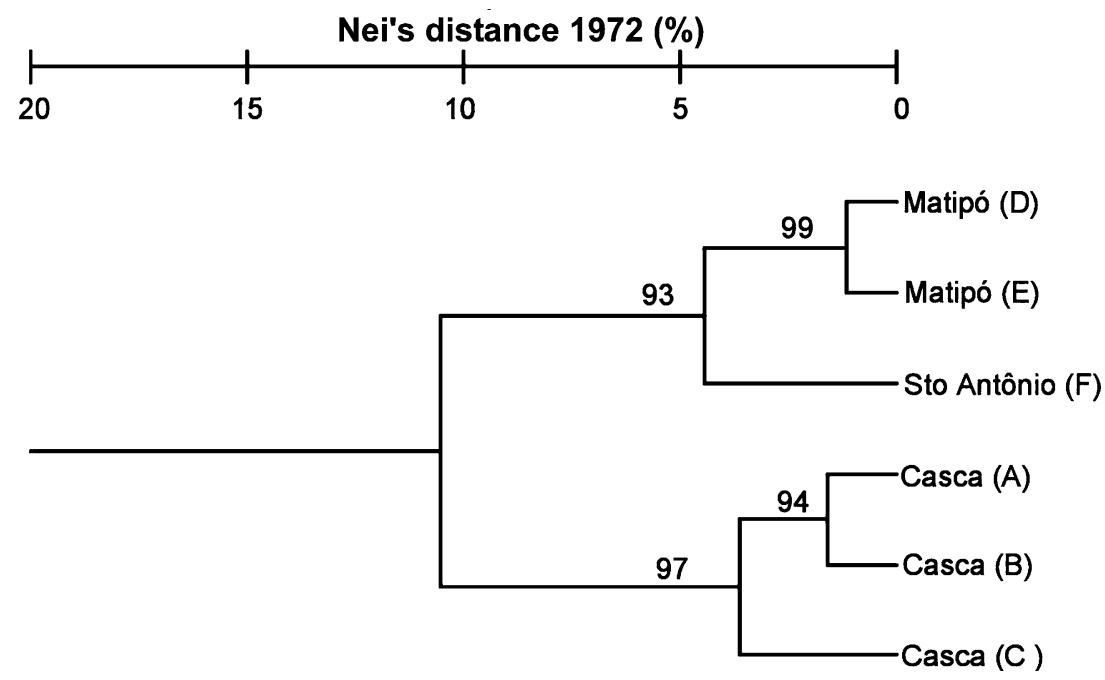

Figure 3. UPGMA dendrogram showing genetic relationships among populations of $A$. bimaculatus from the Doce river basin inferred from Nei's genetic distances matrix. Bootstrap values indicate consistency of data.

and meristic data $p<0.05$ for both lateral line scales and anal ray counts (Fig. 5). In another comparison, molecular and meristic patterns were partially congruent in the Matipó samples, despite they were similar in RAPD markers and meristic Ran character, these samples were statistically different in LL counts. The Santo Antônio river sample, regardless its geographic origin, was more

Table 4. First principal component (CP-1) coefficients and size-free canonical variation (CV) analyses for six samples of A. bimaculatus in the Doce river basin. The latter values are expressed as Pearson correlation coefficients between morphometric characters values and scores obtained by canonical analysis; $r$ is the correlation coefficient between the first eigenvector (CP-1) and each morphometric character

\begin{tabular}{|c|c|c|c|c|}
\hline Character & $\mathrm{CP}-1$ & $r$ & CV-1 & $\mathrm{CV}-2$ \\
\hline SL & 0.253862 & $0.99262 *$ & $-0.09301^{\mathrm{ns}}$ & $-0.35720^{*}$ \\
\hline HL & 0.211542 & $0.94172 *$ & $-0.34816^{*}$ & $0.38096^{*}$ \\
\hline $\mathrm{BH}$ & $0 \cdot 261556$ & $0.97641^{*}$ & $0 \cdot 35401 *$ & $-0.02866^{\mathrm{ns}}$ \\
\hline $\mathrm{CPH}$ & 0.293413 & $0.94871 *$ & $0.05358^{\mathrm{ns}}$ & $-0.06030^{\mathrm{ns}}$ \\
\hline IW & 0.283489 & $0.94647^{*}$ & $-0.27077^{*}$ & $-0.17607^{\mathrm{ns}}$ \\
\hline OD & 0.163794 & $0.90663^{*}$ & $0.08637^{\mathrm{ns}}$ & $0.70928 *$ \\
\hline PD & 0.254093 & $0.96096^{*}$ & $-0.08564^{\mathrm{ns}}$ & $0.15470^{\mathrm{ns}}$ \\
\hline PDD & 0.246453 & $0.98616^{*}$ & $-0.44525^{*}$ & $0.03255^{\mathrm{ns}}$ \\
\hline DPD & $0 \cdot 257711$ & 0.98819* & $0 \cdot 07734^{\mathrm{ns}}$ & $0 \cdot 0398^{\mathrm{ns}}$ \\
\hline PPD & 0.256592 & $0.96833^{*}$ & $0.15620^{\mathrm{ns}}$ & $0.09242^{\mathrm{ns}}$ \\
\hline PAD & 0.321645 & $0.94249 *$ & $0.24308^{*}$ & $-0.14449^{\mathrm{ns}}$ \\
\hline DAD & 0.266810 & $0.98469^{*}$ & $0.25018^{*}$ & $-0.34370^{*}$ \\
\hline AAD & 0.284521 & $0.98782 *$ & $-0.34943^{*}$ & $-0.05588^{\mathrm{ns}}$ \\
\hline DADP & $0 \cdot 271176$ & $0.98588^{*}$ & $-0 \cdot 14722^{\mathrm{ns}}$ & $-0 \cdot 32459^{*}$ \\
\hline $\mathrm{HH}$ & $0 \cdot 205957$ & $0.91312^{*}$ & $0 \cdot 12004^{\mathrm{ns}}$ & $0 \cdot 10898^{\mathrm{ns}}$ \\
\hline
\end{tabular}

${ }^{*} p<0.01$; ns, nonsignificant; SL, standard length; CC, head length; BH, body height; $\mathrm{CPH}$, caudal peduncule height; IW, interorbital width; OD, ocular diameter; PD, pre-anal distance; PDD, pre-dorsal distance; DPD, dorsal-pectoral distance; PPD, pectoral-pelvic distance; PAD, pelvic-anal distance; DAD, dorsal-anal distance; AAD, anal-adipose distance; DADP, dorsal-adipose distance; HH, head height. 


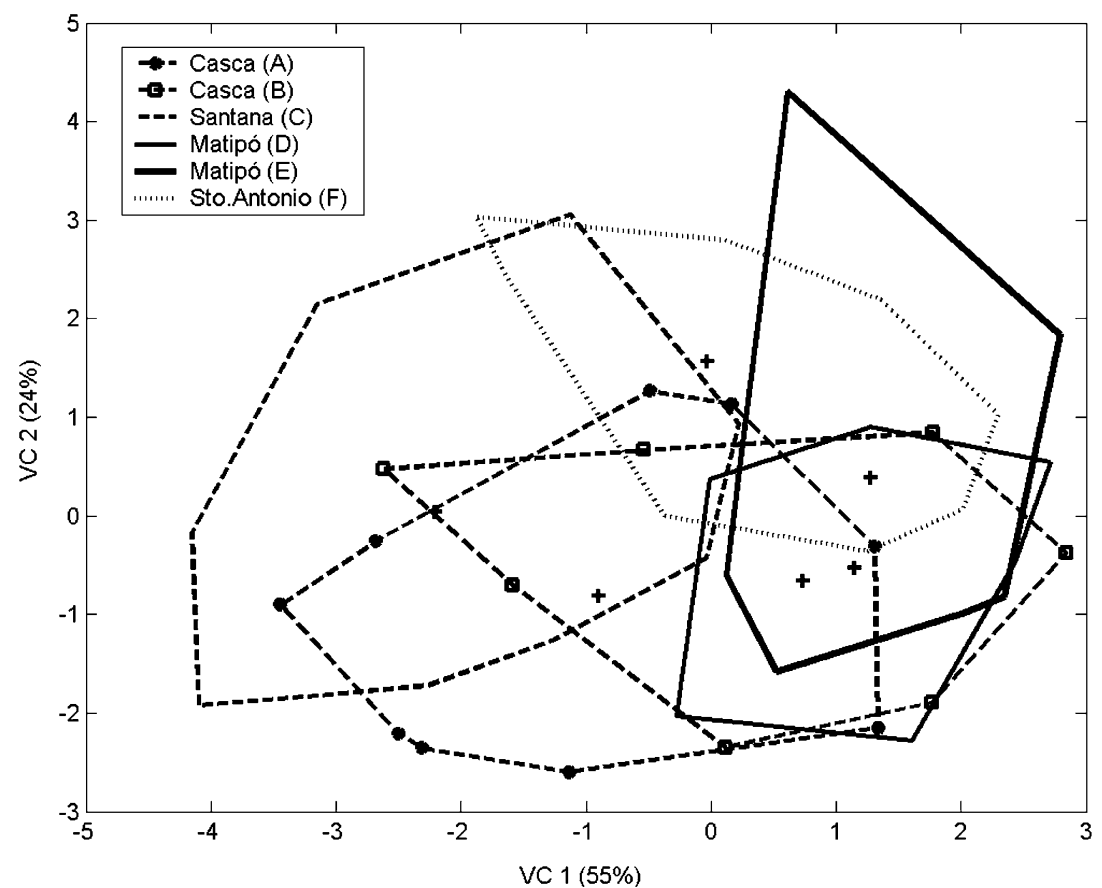

Figure 4. Projection of first and second canonical variables (CV) 1 and 2 taken from a discriminant analysis of the size-independent residuals of morphometric data among six populations of $A$. bimaculatus in the Doce river basin. Convex polygons minimally enclose sets of points for each group; crosses indicate centroids.

similar to Matipó samples in lateral line scales and more similar to Casca samples in anal ray numbers.

\section{Discussion}

In freshwater fish, hierarchic analyses of genetic data indicate variable levels of population structure. Tributary-related levels of variation are reported for Etheostoma flabellare (Faber \& White, 2000), and in Salmo trutta, microsatellite variation seems related to waterfalls and tributaries (Carlsson et al., 1999). In continental species of fish, isoenzyme variation in tributaries is apparently responsible for $22.2 \%$ (Ward et al., 1994) to $32.8 \%$ (Gyllensten, 1985) of total genetic variation. Low levels of variation among samples within major tributaries (2.61\% of AMOVA) and high levels of variation among major tributaries (21.04\% of AMOVA) suggested that A. bimaculatus of the Doce basin also behaved as a short distance migrant, as reported by Uieda (1984) and Garutti (1988) for other drainages. Although in the Doce river basin, large numbers of A. bimaculatus are usually caught while swimming upstream at waterfalls during the rainy season, large rivers are also considered as ecological barriers for these small-sized characins (Garutti \& Britski, 1997; Garutti, 1988).

Quantitative morphometric characters were uniform among samples, suggesting the occurrence of a single species in the basin, a condition already reported for other basins (Garutti \& Britski, 1997). Populations of $A$. bimaculatus seem amenable to morphologic approaches as the same morphometric characters that were informative in this study, such as body height, ocular diameter, interorbital width and head length, have been successfully applied in ecologic studies of this species complex (Garutti \& Figueiredo-Garutti, 1992). Meristic variation such as number of anal fin rays in A. altiparanae (a species that belongs to the same species complex) in the Paraná basin has been interpreted as a result of the action of environmental factors (Garutti, 1993).

The use of simultaneous approaches using independent data sets allows for a more thorough 
(a) Casca
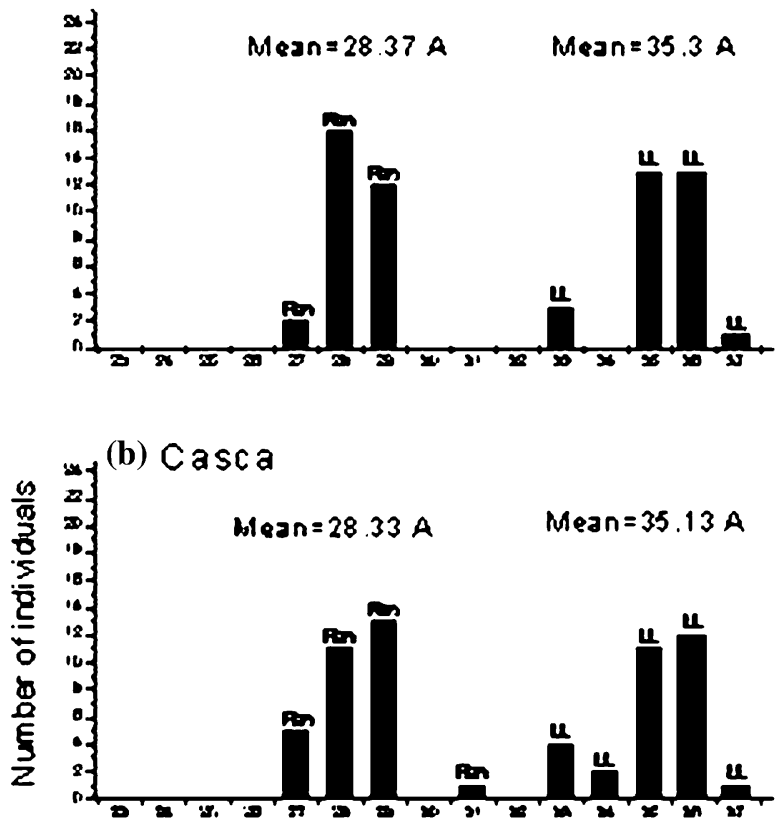

(c) Santana

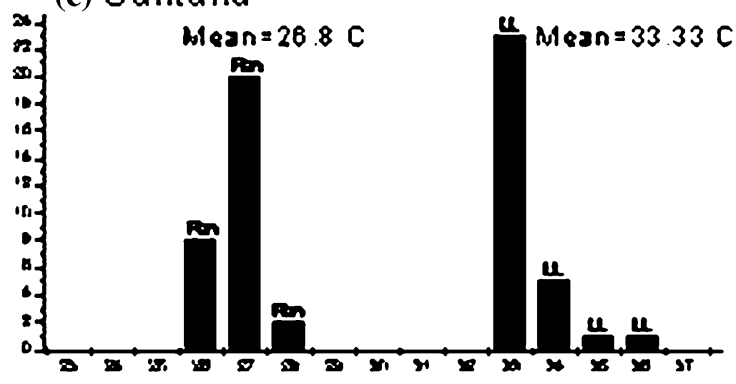

Number of scales lateral line (LL) and number of rays caudal ín (Ran)

(d) Matipó

(e) M atipó

(f) Santo Antônio
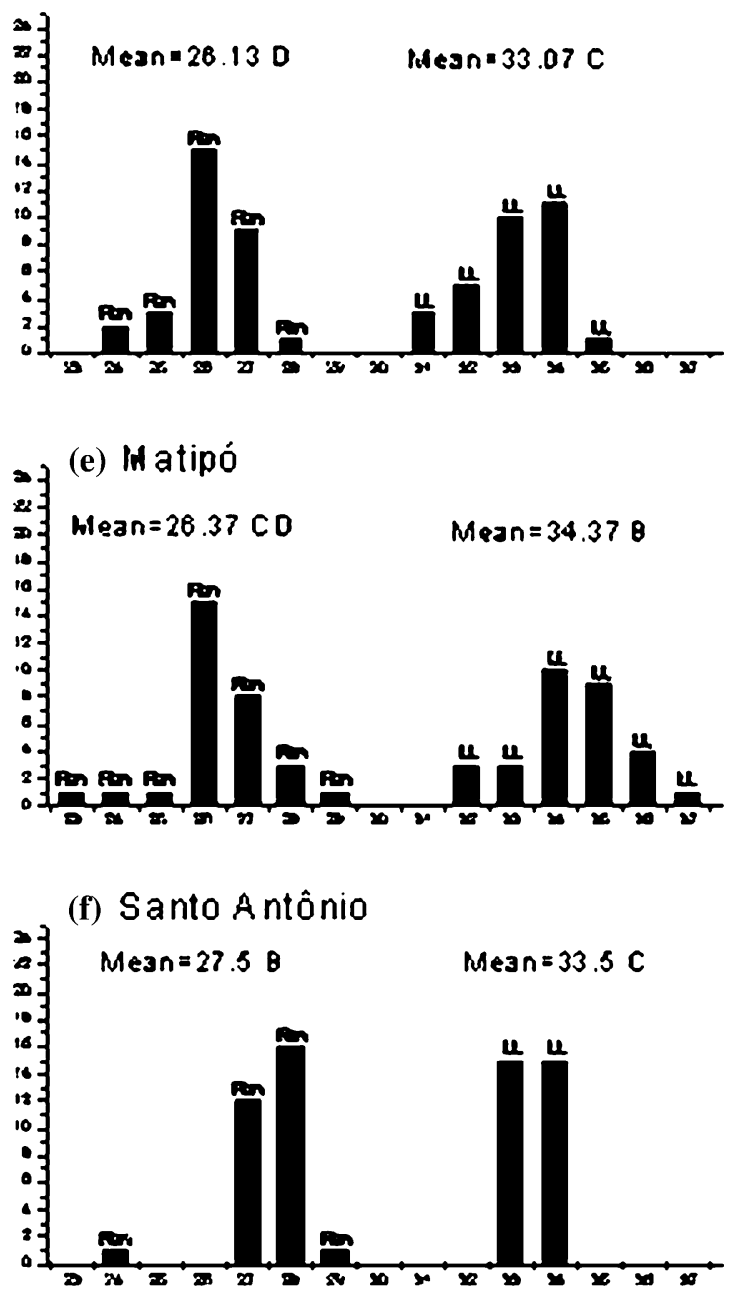

Figure 5. Variation of lateral-line scale (LL) and caudal fin ray numbers (RAN) in samples of $A$. bimaculatus in the Doce basin. Mean values followed by the same letter are not significantly different (Tukey, $\alpha=0.05$ ).

understanding of evolutionary patterns, as each technique has its own resolving power (Reis et al., 1990; Hillis et al., 1996; Boero, 2001) and it has been applied to studies in taxonomy and conservation biology assessments (e.g., Agnèse et al., 1997; Rognon et al., 1998; Salducci et al., 2004). In the Neotropical region, studies with these techniques have included cytogenetics and morphology (Moreira-Filho \& Bertollo, 1991; Mizoguchi \& Martins-Santos, 1998).

Our data were compatible with an isolationby-distance model, also affected by higher-order vicariant processes and independent ecological or evolutionary histories, evidenced by lower levels of genetic diversity in the Casca river samples and high levels of variation in the Matipó river. In the Santo Antônio sample, sampling conditions may have biased our results, because most specimens were collected in a marginal pond. In Casca river samples, similar RAPD-PCR marker frequencies in locales $\mathrm{A}$ and $\mathrm{B}$ was unexpected. The Escura waterfall is an effective barrier for a medium-sized characin, Leporinus copelandii, a strong swimmer and highly migratory species. This pattern would be expected either if (a) the waterfall were not a selective obstacle for the Astyanax species, (b) the 
waterfall was of relatively geological recent age. Waterfalls in this basin are usually considered as Plio-Pleistocene (A. Saadi, University Federal of Minas Gerais, Belo Horizonte/MG, Brazil, pers. com.) and it may not have allowed for genetic differentiation between upriver and downriver populations. Finally, (c) populations isolated by the waterfalls may be large enough to overcome random loss of alleles. In Matipó (locales D and E), all species are present at both sides of the former waterfall of Emboque, now substituted by a dam. Because dams are efficient barriers to gene flow in any direction (Avise \& Felley, 1979; Revaldaves et al., 1997; Neeras \& Spruell, 2001), our data are relevant for suggesting the need for restitution of historical migration in the Matipó river. In the Casca river, the Grande waterfall was the only locale where populations showed the large morphologic and molecular differences. This waterfall is also the highest $(15 \mathrm{~m})$ and probably affects survival of fish swimming downstream. Considering all the evidences, it may be that in the Matipó river, as well as the lower reaches of the Casca rivers, migrants from upstream populations may be the strongest factor in maintaining similarities between populations. Maintenance of large populations would be guaranteed by the generalist behavior of this species (Costa \& Braga, 1993; Esteves \& Galetti, 1995). Divergent molecular frequencies qualify each tributary as a management unit (Moritz, 1994), as also suggested by divergent patterns of meristic characters. Although this species behaves as an $r$-strategist, ecological studies have also reported population differentiation in a related form, A. altiparanae (Orsi et al., 2004). Within the Doce basin, molecular differences accumulate at a fast rate in lacustrine habitats. Significant variation in RAPD-PCR alleles has been reported for a sedentary species (Hoplias malabaricus) inhabiting Quaternary lakes (Dergam et al., 2002). Likewise, Nesbo et al. (1998) observed molecular differences among populations of Perca fluviatilis isolated for 100 years in the Baltic Sea.

\section{Conclusion}

Genetic and morphologic variation of $A$. bimaculatus in the Doce river basin was not necessarily associated with waterfall and dam location. For the major waterfalls, both sets of data were congruent and suggested high levels of population divergence. Tributaries of this river basin may be considered as management units for this species, and overall levels of morphologic variation suggest the existence of a single taxon.

\section{Acknowledgements}

The authors wish to thank the Universidade Federal de Viçosa, Companhia Luz Cataguases Leopoldina, José Lélis, Vitor Tottola and Helvécio Tottola for assistance in fieldwork, two anonymous revisors and Pablo Rodrigues Gonçalves and Aldrin Vieira Pires for helpful comments in the morphological statistical analyses. We also wish to thank Professor Concepta McManus of University of Brasilia for proof-reading the manuscript.

\section{References}

Aagaard, J. E., K. V. Krutovskii \& S. H. Strauss, 1998. RAPDs and allozymes exhibit similar levels of diversity and differentiation among populations and races of Douglas-fir. Heredity 81: 69-78.

Agostinho, A. A., L. M. Bini \& L. C. Gomes, 1997. Ecologia de comunidades de peixes da área de influência do reservatório de Segredo. In Agostinho, A. A. \& L. M. Gomes (eds), Reservatório de Segredo, bases ecológicas para manejo. EDUEM, Maringá: 97-111.

Agnèse, J. F., G. G. Teugels, P. Galbusera, R. Guyomard \& F. Volckaert, 1997. Morphometric and genetic characterization of sympatric populations of Clarias gariepinus and C.anguillaris from Senegal. Journal of Fish Biology 50: 11431157.

Avise, J. C. \& J. Felley, 1979. Population structure of freshwarter fishes. 1. Genetic variation of bluegill (Lepomis macrochirus) populations in man-made reservoirs. Evolution 33: 15-26.

Bartish, L. V., N. Jeppson \& H. Nybom, 1999. Population genetic structure in the dioecious pioneer plant species Hippophae rhamnoides investigated by random amplified polymorphic DNA (RAPD) markers. Molecular Ecology 8: 791802.

Bazzoli, N., E. Rizzo, H. Chiarini-Garcia \& R. M. A. Ferreira, 1991. Ichthyofauna of the Paranaíba river in the area to be flooded by the Bocaina reservoir, Minas Gerais, Brazil. Ciência e Cultura 43: 451-454.

Boero, F., 2001. Light after dark: the partnership for enhancing expertise in taxonomy. Trends in Ecology and Evolution 16: 266. 
Bohonak, A. J., 2002. IBD (Isolation By Distance): a program for analyses of isolation by distance. The Jounal of Heredity 93: 153-154.

Bookstein, F., B. Chernoff, R. Elder, J. Humphries, G. Smith \& R. Strauss, 1985. Morphometrics in Evolutionary Biology. Special publication 15, The Academy of Natural Sciences of Philadelphia, 277 pp.

Boyce, T. M., M. E. Zwick \& C. F. Aquadro, 1989. Mitochondrial DNA in bark weevils: size, structure, and heteroplasmy. Genetics 123: 825-836.

Carlsson, J., K. H. Olsén, J. Nilsson, O. Overli \& O. B. Stabell, 1999. Microsatellites reveal fine-scale genetic structure in stream-living brown trout. Journal of Fish Biology 55: 12901303.

Costa, F. E. dos S. \& F. M. de S. Braga, 1993. Estudo da alimentação natural de Astyanax bimaculatus, Astyanax schubati e Moenkhausia intermedia (Characidae, Tetragonopterinae) na represa de Barra Bonita, rio Piracicaba (SP) Revista UNIMAR 15: 117-134.

Dergam, J. A., S. R. Paiva, C. E. Schaeffer, A. L. Godinho \& F. Vieira, 2002. Phylogeography and RAPD-PCR variation in Hoplias malabaricus (Pisces, Teleostei) in southeastern Brazil. Genetics and Molecular Biology 25: 379-388.

Efron, B., 1985. Bootstrap confidence intervals for a class of parametric problems. Biometrika 72: 45-58.

Eigenmann, C. H. 1921. The American Characidae. Memories American Museum 43: 1-428, 90 pls.

Esteves, K. E. \& P. M. Galetti Jr., 1995. Food partitioning among some characids of a small Brazilian floodplain lake from the Paraná River basin. Environmental Biology of Fishes 42: 375-389.

Excoffier, L., P. E. Smouse \& J. M. Quattro, 1992. Analysis of molecular variance inferred from metric distances among DNA haplotypes: application to human mitochondrial DNA data. Genetics 131: 479-491.

Faber, J. E. \& M. M. White, 2000. Comparison of gene flow estimates between species of darters in different streams. Journal of Fish Biology 57: 1465-1473.

Fritsch, P. \& L. H. Rieseberg, 1996. The use of Random Amplified Polymorphic DNA (RAPD) in conservation genetics. In Smith, T. B. \& R. K. Wayne (eds), Molecular Genetic Approaches in Conservation. Oxford Press University, New York, 54-73.

Garutti, V., 1988. Distribuição longitudinal da ictiofauna em um córrego da região noroeste do estado de São Paulo, bacia do rio Paraná. Revista Brasileira Biologia 48: 747-759.

Garutti, V., 1993. Raios da nadadeira anal de Astyanax bimaculatus (Pisces, Characidae) procedente da região noroeste do Estado de São Paulo, bacia do rio Paraná. Revista Brasileira Biologia 53: 159-166.

Garutti, V. \& H. A. Britski, 1997. Descrição de uma espécie nova de Astyanax (Teleostei, Characidae), com mancha umeral horizontalmente ovalada, da bacia do Rio Guaporé, Amazônia. Papéis Avulsos de Zoologia 40: 217-229.

Garutti, V. \& M. L. Figueiredo-Garutti, 1992. Caracterização de populações do lambari Astyanax bimaculatus (Pisces, Characidae), procedentes do campus de Jaboticabal, UNESP, SP. Naturalia 17: 17-29.
Gyllensten, U. B., 1985. The genetic structure of fish: differences in the intraspecific distribution of biochemical genetic variation between marine, anadromous, and freshwater species. Journal of Fish Biology 26: 691-699.

Hadrys, H., M. Balick \& B. Schierwater, 1992. Applications of random amplified polymorphic DNA (RAPD) in molecular ecology. Molecular Ecology 1: 55-63.

Hillis, D. M., C. Moritz \& B. K. Mable, 1996. Molecular Systematics, 2nd edn. Sinauer Associates, Inc., Sunderland, $655 \mathrm{pp}$.

Hiss, R. H., D. E. Norris, C. R. Dietrich, R. F. Whitcomb, D. F. West, C. F. Bosio, S. Kambhampati, J. Peisman, M. F. Antolin \& W. C. Black IV, 1994. Molecular taxonomy using single strand conformation polymorphism (SSCP) analysis of mitochondrial DNA genes. Insect Molecular Biology 2: 171-182.

Holm, S., 1979. A simple sequentially rejective multiple test procedure. Scandinavian Journal of Statistics 6: 65-75.

Hsiao, J. Y. \& L. C. Liao, 1998. Relationship between population genetic structure and riparian habitat as revealed by RAPD analysis of the rheophyte Acorus gramineus Soloand (Araceae) in Taiwan. Molecular Ecology 7: 1275-1281.

Jolicoeur, P., 1963. The multivariate generalization of the allometry equation. Biometrics 19: 497-499.

Lacerda, D. R., M. D. P. Acedo, J. P. Lemos Filho \& M. B. Lovato, 2001. Genetic diversity and structure of natural populations of Plathymenia reticulata (Mimosoideae), a tropical tree from the Brazilian Cerrado. Molecular Ecology 10: 1143-1152.

Lagler, K. F., J. E. Bardach, R. R. Miller \& D. R. N. Passino, 1977. Ichthyology, 2nd edn., John Wiley, \& Sons, 506 pp.

Lamas, I. R. 1993. Análise de características reprodutivas de peixes brasileiros de água doce, com ênfase no local de desova. Unpubl. Masters Dissertation. Instituto de Ciências Biológicas. Universidade Federal de Minas Gerais. Belo Horizonte, Brazil, 72 pp.

Lima, F., L. R. Malabarba, P. A. Buckup, J. F. Pezzi da Silva, R. P. Vari, A. Harold, R. Benine, O. T. Oyakawa et al., 2003. In Reis, R. E., S. O. Kullander \& C. J. Ferraris Jr. (eds), Genera incertae sedis in Characidae. EDIPUCRS, Porto Alegre, Brazil: 106-169.

Lynch, M. \& B. G. Milligan, 1994. Analysis of population genetic structure with RAPD makers. Molecular Ecology 3: 91-99.

Martins, S. L. \& K. Tamada, 2000. Sistemas para transposição de peixes. Boletim Técnico da Escola Politécnica da USP, Departamento de Engenharia Hidráulica e Sanitária, São Paulo, $27 \mathrm{pp}$.

Miller, M. P., 1997. Tools for population genetics analyses (TFPGA): a Windows program for the analysis of allozyme and molecular population genetic data. Available in $<$ http://herb.bio.nau.edul miller/tfpga.htm $>$.

Mizoguchi, S. M. H. N. \& I. C. Martins-Santos, 1998. Cytogenetic and morphometric differences in populations of Astyanax "scabripinnis" (Pisces, Characidade) from Maringá region, PR, Brazil. Genetics and Molecular Biology 21: $55-61$. 
Moreira-Filho, O. \& L. A. C. Bertollo, 1991. Astyanax scabripinnnis (Pisces, Characidae): a species complex. Revista Brasileira Genética 14: 331-357.

Moritz, C., 1994. Defining 'Evolutionary Significant Units' for conservation. Trends in Ecology and Evolution 9: 373375 .

Meffe, G. K. \& C. R. Carroll, 1997. Principles of Conservation Biology. Sinauer Associates, Inc., Sunderland, Massachusetts, 729 pp.

Naish, K. A., M. Warren, F. Bardakci, D. O. F. Skibinski, G. R. Carvalho \& G. C. Mair, 1995. Multilocus DNA fingerprinting and RAPD reveal similar genetic relationships between strains of Oreochromis niloticus (Pisces: Cichlidae). Molecular Ecology 4: 271-274.

Nei, M., 1972. Genetic distance between populations. American Naturalist 106: 283-292.

Nesbo, C. L., C. Magnhagen \& K. S. Jakobsen, 1998. Genetic differentiation among stationary and anadromous perch (Perca fluviatilis) in the Baltic Sea. Hereditas 129: 241-249.

Neraas, L. P. \& P. Spruell, 2001. Fragmentation of riverine systems: the genetic effects of dams on bull trout (Salvelinus confluentus) in the Clark Fork River system. Molecular Ecology 10: 1153-1164.

Orsi, M. L., E. D. Carvalho \& F. Foresti, 2004. Biologia populacional de Astyanax altiparanae Garutti, Britski (Teleostei, Characidae) do médio Rio Paranapanema, Paraná, Brasil. Revista Brasileira de Zoologia 21: 207-218.

Peres-Neto, P. R., 1995. Introdução a análises morfométricas. In Peres-Neto, P. R., J. L. Valentin, \& F. Fernandez (eds) Tópicos em Tratamentos de Dados Biológicos. Oecologia Brasiliensis. II Universidade Federal do Rio de Janeiro, Instituto de Biologia, Programa de Pós-Graduação em Ecologia, Rio de Janeiro,, 57-89.

Raymond, M. L. \& F. Rousset, 1995. An exact test for population differentiation. Evolution 49: 1280-1283.

Reis, S. F., L. M. Pessôa \& R. E. Strauss, 1990. Application of sizefree cannonical discriminant analysis to studies of geographic differentiation. Revista Brasileira Genética 13: 509-520.

Revaldaves, E., E. Renesto \& M. F. P. S. Machado, 1997. Genetic variability of Prochilodus lineatus (Characiformes, Prochilodontidae) in the upper Paraná river. Brazilian Journal of Genetics 20: 381-388.

Rognon, X., G. G. Teugels, R. Guyomard, P. Galbusera, M. Andriamanga, F. Volckaert \& J. F. Agnèse, 1998. Morphometric and allozyme variation in the African catfishes Clarias gariepinus and C. anguillaris. Journal of Fish Biology 53: 192-207.
Salducci, M. D., J. F. Martin, N. Pech, R. Chappaz, C. Costedoat \& A. Gilles, 2004. Deciphering the evolutionary biology of freshwater fish using multiple approaches-insights for the biological conservation of the Vairone (Leuciscus souffia souffia). Conservation Genetics 5: 63-77.

SAS Institute Inc., 1997. SAS/STAT User's Guide, Version 6, 5 th edn., SAS Institute, Inc, Cary, NC.

Schaffer, H. E. \& R. R. Sederoff, 1981. Improved estimation of DNA fragment lengths from agarose gels. Analytical Biochemistry 115: 113-122.

Schaefer, S. A., 1998. Conflict and resolution: impact of new taxa on Phylogenetic studies of the Neotropical cascudinhos (Siluroidei: Loricariidae). In Malabarba, L. R., R. E. Reis, R. P. Vari, Z. M. S. Lucena, \& C. A. S. Lucena (eds), Phylogeny and classification of Neotropical fishes. EDIPUCRS, Porto Alegre, $603 \mathrm{pp}$.

Schneider, S., D. Roessli \& L. Excoffier, 2000. Arlequin, ver.2.000: A Software for Population Genetic Data Analysis. Genetics and Biometry Laboratory, University of Geneva, Switzerland, $113 \mathrm{pp}$.

Sokal, R. \& F. J. Rohlf, 1995. Biometry, 3rd edn. W. H. Freeman and Co., New York.

Strauss, R. E., 1985. Evolutionary allometry and variation in body form in the South American catfish genus Corydoras (Callichthyidade). Systematic Zoology 34: 381-396.

Sun, G. L., O. Días, B. Salomón \& R. Von Bothmer, 1998. Microsatellite variation and its comparison with allozyme and RAPD variation in Elymus fribrosus (Schrenk) Tzvel. (Poaceae). Hereditas 129: 275-282.

Uieda, V. S., 1984. Ocorrência e distribuição dos peixes em um riacho de água doce. Brazilian Journal of Biology 44: 203-213.

Vucetich, L. M., J. A. Vucetich, C. P. Joshi, T. A. Waite \& R. O. Peterson, 2001. Genetic (RAPD) diversity in Peromyscus maniculatus populations in a naturally fragmented landscape. Molecular Ecology 10: 35-40.

Ward, R. D., M. Woodwark \& D. O. F. Skibinski, 1994. A comparison of genetic levels in marine, freshwater, and anadromus fishes. Journal of Fish Biology 44: 213-232.

Welsh, J. \& M. McClelland, 1990. Fingerprinting genomes using PCR with arbitrary primers. Nucleic Acids Research 18: 7213-7218.

Williams, J. G. K., A. R. Kubelik, K. J. Livak, J. A. Rafalski \& S. V. Tingey, 1990. DNA polymorphisms amplified by arbitrary primers are useful as genetics markers. Nucleic Acids Research 18: 6531-6535.

Wright, S., 1951. The genetical structure of populations. Annals of Eugenics 15: 323-354. 